\title{
Hasil belajar model discovery learning dalam peningkatan partisipasi belajar pembelajaran PPKn kelas X SMAN 1 Lemahabang
}

\author{
Suhimo ${ }^{a, 1^{*}}$, Yudi Firmansyah ${ }^{b, 2}$, Erwin Susanto ${ }^{c, 3}$ \\ abc Pendidikan Pancasila dan Kewarganegaraan, Universitas Buana Perjuangan Karawang, Indonesia \\ ${ }^{1}$ pk16.suhimo@mhs.ubpkarawang.ac.id \\ *korespondensi penulis
}

\begin{abstract}
ABSTRAK
Penelitian ini bertujuan untuk mengetahui hasil belajar dalam peningkatan partisipasi belajar model discovery learning dalam pembelajaran Pendidikan Pancasila dan Kewarganegaraan siswa kelas X SMAN 1 Lemahabang. Penelitian ini menggunakan pendekatan kualitatif dengan metode deskriftif. Subjek dalam penelitian ini ialah guru PPKn, siswa Kelas X, wakasek kurikulum, teknik pengumpulan data dalam penelitian ini terdiri dari observasi, wawancara, dokumentasi. teknik analisis data dalam penelitian ini adalah triangulaasi. Hasil penelitian menunjukan bahwa hasil belajar ketika menerapkan model discovery learning Pendidikan Pancasila dan Kewarganegaraan partisipasi belajar siswa meningkat, siswa juga lebih aktif pada saat pembelajaran berlangsung, siswa juga terbiasa untuk menyampaikan pendapatnya sendiri. Rekomendasi penelitian ini, bagi sekolah selaku pemangku kebijakan diharapkan untuk mendukung guru ketika menerapkan model discovery learning untuk mendapatkan hasil belajar yang maksimal, bagi guru diharapkan untuk selalu menerapkan model discovery learning secara maksimal untuk mencapai hasil belajar yang diharapkan, bagi siswa diharapkan ketika guru menerapkan model discovery learning dalam pembelajar siswa menjadi lebih aktif pada saat pembelajaran berlangsung.
\end{abstract}

\begin{abstract}
This research aims to investigate the learning outcomes and the learning participation during the discovery learning model in learning process of Pancasila and Civics Education in the 10thgrade of SMAN 1 Lemahabang. This research used a qualitative approach with a descriptive method. The subjects of this research are the teacher of Pancasila and Civics Education, students of the 10th-grade, and the academic vice-principal, the data collection techniques used in this research are interviews, context documentation, and observations. The data analysis technique used in this research is triangulation, in which the data are collected through observations, interviews, and context documentation. The result of research shows that the learning outcomes during the implementation of discovery learning model increasingly achieved, furthermore, the students were more active during the learning process, on top of that, the students were also accustomed to expressing their own opinions. These are the recommendations from this research. For school as the policymaker, they are supposed to support the teacher in implementing the discovery learning model to achieve maximum learning outcomes. For teachers, they are supposed to always implementing the discovery learning model maximally to achieve the expected learning outcomes. For students, at the time teacher used the discovery learning model in class, they are supposed to be more active during the learning process.
\end{abstract}

Sejarah Artikel

Diterima: 5 Januari 2021

Disetujui: 19 Februari 2021

Kata kunci:

Discovery learning

Partisipasi belajar

Hasil belajar

Article's Information:

Received: 5 January 2021

Accepted: 19 February 2021

Keywords:

Discovery learning

Learning participation

Learning outcomes

\section{Pendahuluan}

Setiap pembelajaran tentunya memiliki tujuan pembelajaran dan hasil belajar yang ingin dicapai ketika suatu pembelajaran telah mencapai dari akhir dari proses belajar mengajar selesai yang telah dilaksanakan oleh siswa. hasil dari pembelajaran bisa dikatakan berhasil ketika siswa mengalami pebuhan dilihat dari segi perkembangan kognitif, afektif, dan psikomotorik siswa setelah pembelajaran selesai, setiap siswa ketika mengkuti proses pembelajaran ada beberapa siswa yang

Korespondensi: Suhimo, pk16.suhimo@mhs.ubpkarawang.ac.id, Pendidikan Pancasila dan Kewarganegaraan, Universitas Buana Perjuangan Karawang, Karawang, Indonesia

Copyright (C2021. CIVICS: Jurnal Pendidikan Pancasila dan Kewarganegaraan 
lambat untuk menerima materi pelajar pada saat guru mengajar di dalam kelas. Ada beberapa faktor yang mempengaruhi keberhasilan capaian pembelajaran diantaranya belum siapnya siswa mengikuti pembelajaran, kurangnya pengunaan model pembelajaran, strategi pembelajaran, media pembelajaran yang digunakan oleh guru ketika menyajikan materi kepada siswa. Maka perlunya menggunakan model pembelajaran yang bervareatif ketika guru mengajar di dalam kelas dengan penggunaan model pembelajara dan strategi pembelajaran.

Karena hasil belajar bukanlah hanya berbentuk nilai saja yang diperoleh oleh siswa dengan KKM (kriteria ketuntasan minimal) setelah mengikuti pembelajaran sampai dengan selesai, dengan kata lain hasil belajar ialah mencakup perubahan dan perkembangan siswa dilihat dari perubahan kognitif, afektif, dan psikomotorik yang ada disetiap individu siswa sejalan dengan apa yang dikemukan menurut Slameto (2010:18) Belajar merupakan kegiatan manusia yang berakal, pengetahuan, sikap dan keterampilan akan terbentuk, termodifikasi serta berkembangmelalui proses belajar. Belajar adalah perubahan tingkah laku pada diri individu sebagaiakibat dari pengalaman. Oleh karena itu seseorang dikatakan belajar bila didalam dirinya terjadi suatu proses kegiatan yang mengakibatkan perubahan tingkah laku. Perubahan tingkah laku ini disertai usaha, karena tanpa usaha tidak dapat dikatakan belajar. Hasil belajar merupakan perubahan tingkah laku pada setiap indivu siswa setelah mengikuti pembelajaran, karena pembelajaran bukan hanya hanya untuk mendapatkan pengetahuan saja melainkan pembelajaran juga membimbing siswa untuk mempersiapakan kehidupan siswa kemudian hari nanti.

Mata pembelajaran PPKn sering dipandang oleh siswa kelas $X$ mata pelajaran yang menjenuhkan karena guru ketika mengajar di dalam kelas sering kali menggunkan motede cerah cerah. Maka dari itu ini sangat mempengaruhi kepada hasil belaajar siswa yang kurang maksimal, pemilihan model pembelajaran dalam penyajian materi peljaran PPKn, yang akan dipelajari oleh siswa kelas $\mathrm{X}$ tentunya harus dapat menarik perhatian siswa agar siswa terlibat aktif pada saat proses belajar mengajar. Padahal, PPKn itu penting karena: more important are the activities that people not only understand in theory but was able to participate on the grounds that they understand the concept and what it does impact on them (Susanto \& Saylendra, 2018). Yang berarti untuk membentuk warga negara yang baik diperlukan warganegara yang tidak hanya paham teori tetapi juga mampu melaksanakan teori tersebut, dan PPKn merupakan salah satu upaya dalam konteks tersebut. Pemilihan model pembelajaran discovery learning dalam mata pelajaran PPKn dapat memberikan kontribusi terhadap masalah-masalah pembelajaran yang dialami siswa, khususnya dalam peningkatan pemahaman konsep-konsep maupun pengembangan sikap ilmiah. Model pembelajaran yang ditekankan pada kurikulum 2013 ini adalah mengutamakan model pembelajaran disovery learning, problem based learning dan project based learning. Penemuan (discovery) merupakan suatu model pembelajaran yang dikembangkan berdasarkan pandangan konstruktivisme. Model ini menekankan pentingnya pemahaman struktur atau ide-ide penting terhadap suatu disiplin ilmu, melalui keterlibatan siswa secara aktif dalam pembelajaran. dengan penerapan model pembelajaran discovery learning dalam proses pembelajaran PPKn di kelas $X$ dapat meningkat partisipasi belajar siswa yang diharapkan oleh guru, sehingga pada saat penerapn model pembelajaran discovery learning akan memberikan dampak positif kepada siswa terutama hasil belajar yang maksimal. Ketika penerapan model pembelajaran discovery learning siswa dituntut untuk aktif pada saat pembelajaran berlangsung, dengan penerapan model ini guru hanya sebagai fasilitator saja. Pada pembelajaran PPKn dengan menerapkan model pembelajaran discovery learning siswa juga terbiasa untuk 
melakukan pengamatan, mencari informasi dari berbagai sumber, dapat menyimpulkan dari hasil pengamatan dengan cara diskusi dengan teman sekolmpoknya. Dengan penerapan model ini siswa belajar tidak terpaku kepada buku paket dan LKS melain siswa diarahkan untuk dapat belajar secara mandiri karena guru menyajikan materi tidak berbentuk final, maka dengan penerapan model pembelajaran discovery learning dalam pembelajaran PPKn di kelas $X$ akan memberikan hasil belajar yang maksimal. Penggunaan model pembelajaran yang tepat dan sesuai dengan kondisi materi yang diajarkan sangat mempengaruhi kegiatan pembelajaran baik proses maupun hasil belajar dan meningkatnya partisipasi belajar siswa. Berdasarkan latar belakang yang telah diuraikan diatas, maka perlu dilakukan penelitian tentang penerapan model Disovery Learning untuk meningkatkan partisipasi pembelajaran dan hasil belajar kognitif siswa pada pembelajaran PPKn $X$ SMAN 1 Lemahabang.

\section{Metode}

Metode penelitian yang digunakan dalam penelitian adalah kualitatif deskriptif. Menurut Sugiyono (2012:13) metode penelitian kualitatif adalah: "Metode penelitian kualitatif dapat diartikan sebagai metode penelitian yang berlandaskan pada filsafat postpositivisme, digunakan untuk meneliti pada kondisi obyek yang alamiah, (sebagai lawannya adalah eksperimen) dimana peneliti sebagai instrumen kunci, teknik pengumpulan data dilakukan secara trigulasi (gabungan), analisis data bersifat induktif/kualitatif, dan hasil penelitian kualitatif lebih menekankan makna dari pada generalisasi." Menurut Sugiyono (2014:53) pendekatan deskriptif adalah: " penelitian deskriftif merupakan penelitian yang dilakukan untuk mengetahui keberadaan variabel mandiri, baik hanya pada satu variabel atau lebih tanpa membuat perbandingan atau menghubungkan dengan variabel lain (variabel mandiri adalah variabel yang berdiri sendiri, bukan indivenden selalu dipasangkan dengan dengan dependen)." Metode penelitian yang digunakan dalam penelitian ini adalah deskriptif kualitatif karena penelitian berjuan untuk mendeskripsikan atau menggambarkan tentang penerapan model discovery learning untuk meningkatkan partisipasi belajar siswa dalam pelajaran PPKn.

\section{Hasil dan Pembahasan}

Hasil dari penerapan model pembelajaran discovery learning dalam pembelajaran PPKn untuk meningkatkan partisipasi belajar siswa kelas X SMAN 1 Lemahabang. Hasil belajar dengan penerapan model pembelajaran discovery learning, yang diterapkan oleh guru dalam pembelajaran memberikan dampak positif terhadap proses belajar siswa, karena dengan menerapkan pembelajaran model pembelajaran ini siswa dituntut untuk dapat berfikir kreatif dan dapat menyampaikan pendapatnya. Untuk memulai sebuah proses belajar mengajar guru perlu menyiapkan perencanaan pembelajaran terlebih dahulu, mulai dari materi yang akan dipelajri oleh siswa, tujuan pembelajaran capaian. Pembelajaran dan lainya dalam peneran model discovery learning guru menggunakan metode diskusi atau siswa dibagi menjadi beberapa, kelompok yang dimana setiap kelompok diberikan pembehasan yang berbeda. Dengan model antusias dan partisipas belajar sangatlah baik, terutama saat siswa menyampaikan pendapatnya sendiri, sehingga tingkat kepercayaan diri siswa meningkat walaupun dalam penerapaan model ini tentunya guru mengahadapi hambatan dan kendala saat berlangsung nya proses belajar mengajar. Karena setiap siswa memiliki karakteristik yang berbeda, karena tingkat keberhasilan dalam proses pembelajara dapat dilihat dari antusias dan partisipasi belajar siswa dapat meningkat dengan demikian dapat dikatakan hasil dan tujaun pembelajaran dapat tercapai. Sejalan dengan pendapat yang di kekukakan oleh para ahli yaitu sebagai berikut Hasil 
belajar menurut Hamalik (2008:5) mengemukakan sebagai berikut, "Hasil belajar ialah sebagai terjadinya perubahan tingkah laku pada diri seseorang yang dapat di amati dan di ukur bentuk pengetahuan, sikap dan keterampilan. Perubahan tersebut dapat diartikan sebagai terjadinya peningkatan dan pengembangan yang lebih baik sebelumnya yang tidak tahu menjadi tahu". Setiap pembelajar tentunya mempunyai capaian yang harus dicapai khususnya dalam pembelajaran. hasil belajar ini tentunya sudah dirancang oleh guru dalam sebuah RPP yang telah dibuat sebelum mengajar didalam kelas. Hasil pembelajaran adalah perubhahan tingkah laku siswa yang terjadi setelah mengikuti pembelajaran. Perubahan tersebut meliputi aspek kognitif, efektif, dan psikomotorik bahwa hasil belajar adalah prestasi yang dicapai oleh siswa ketika setelah mengikuti dalam proses belajar mengajar dengan membawa suatu perubahan dan tingkah laku seseorang. Sedangakan menurut Mulyasa,(2008) mengemukan hasil belajar sebagai berikut. "Hasil belajar ialah prestasi belajar siswa secara keseluruhan yang menjadi indikator kompetensi dan derajat perubahan prilaku yang bersangkutan. Kompetensi yang harus dikuasai siswa perlu dinyatakan sedemikian rupa agar dapat dinilai sebagai wujud hasil belajar siswa yang mengacu pada pengalaman langsung". Untuk mengatakan bahwa suatu proses pembelajaran berhasil, setiap guru memiliki pandangannya masingmasing misalnya pemahaman materi yang dapat ditangkap olehsiswa, pengalaman belajar yang didaptkan oleh siswa, dan nilai yang cukup baik yang di peroleh oleh siswa. Dapat dilihat dari seajauh mana siswa dapat menguasai materi-materi yang telah telah didapat dari proses belajar, karena hasil dari sebuah proses bekan saja berupa nilai atau angka yang didapatkan oleh siswa, tetapi keberhasilan dari sebuah proses pembelajaran juga dapat dilihat dari perubahan sikap siswa. yang tadinya wawasan siswa kurang dalam segi pengetahuan namun setelah mengikuti pembelajaran yang dipelajari didalam proses pembelajaran wawasan siswa menjadi laus yang tadinya tidak tahu menjadi tahu terutama teantang materi-materi pembelajaran.Hasil pembelajaran dengan menggunakan model pembelajaran discovery learning sangatlah memberikan pengaruh positif yang dapat dirasakan oleh siswa terutama ketika siswa mampu berpendapat dengan apa yang ia dapatkan setelah melakuka pengamatan materi pembelajaran, menyajikan data, dan dapat menyimpulkan materi pembvelajaran dengan sangat baik. Bisa dikatakan dengan model pembelajaran discovery learning siswa terlibat aktif dalam pembelajaran. adapun pendapat yang sejalan denga hasil belajar denga diterapkanya model pembelajaran discovery learning menurut Martinis (2007:82) " menegaskan dengan belajar aktif siswa berusaha membangun pengetahuan dalam dirinya sehingga dalam proses pembelajaran terjadi perubahan peningkatan mutu kemampuan, pengetahuan dan keterampilan siswa baik dalam ranah kognitif, psikomotorik dan afektif". untuk mencari dan merumuskan model pembelajaran yang dapat merangkul semua perbedaan yang dimiliki oleh siswa didik. Model pembelajaran yang ditawarkan itu adalah model Berdasarkan pendapat diatas dapat disimpulkan penerapan model pembelajaran discovery learning mampu memberikan hasil yang positif terhadap kualitas proses dan hasil belajar.

Penerapan model pembelajaran discovery learning dapat memberikan hasil positif terhadap hasil belajar peserta didik. Model pembelajar discovery learning, juga diharapkan dapat memberikan pengaruh pada akhirnya juga diharapkan dapat membiasakan peserta didik untuk melakukan proses yang diyakini dapat membuat pembelajaran semakin bermakna. Penggunaan model pembelajaran sangatlah penting terutama guru harus bisa menyesuaikan model pembelajaran dengan materi yang akan diajarkan kepada peserta didik agar pembelajaran terarah dan mendapatkan hasil belajar yang baik, ketika menggunakan model pembelajaran discovery learning seorang guru harus mampu meningkatkan hasil belajar siswa dari segi kognitif, psikomotorik, dan afektif sehingga siswa mampu belajar dengan mandiri. Dari berbagai jenis model pembelajaran yang ada, peneliti memilih menerapkan model discovery learning. Model pembelajaran discovery learning merupakan suatu 
model pemecahan masalah yang akan bermanfaat bagi anak didik dalam menghadapi kehidupannya di kemudian hari.

\section{Simpulan}

Penggunaan model pembelajaran sangatlah penting terutama guru harus bisa menyesuaikan model pembelajaran dengan materi yang akan diajarkan kepada peserta didik agar pembelajaran terarah dan mendapatkan hasil belajar yang baik, ketika menggunakan model pembelajaran discovery learning seorang guru harus mampu meningkatkan hasil belajar siswa dari segi kognitif, psikomotorik, dan afektif sehingga siswa mampu belajar dengan mandiri.

\section{Ucapan Terima Kasih}

Penulis mengucapkan banyak terimakasih kepada semua pihak yang telah membantu dan mendukung penulis dalam menyelesaikan penelitian ini. Ibu, bapak, keluarga tercint, ibu dan bapak dosen, sahabat dan teman-teman semuany, terima kasih banyak penulis haturkan semoga kebaikan teman-teman sekalian dibalas oleh Allah SWT.

\section{Referensi}

Hamalik, O. (2008). Kurikulum dan Pembelajaran. Jakarta: PT. Bumi Aksara.

Mulyasa. (2009). Kurikulum Berbasis Kompetensi. Bandung: PT Rosdakarya.

Rosarina dkk. (2016). Penerapan Model Discovery Learning Untuk Meningkatkan Hasil Belajar Siswa Pada Materi Perubahan Wujud Benda. Jurnal Pena Ilmiah: Vol. 1, No. 1 hlm 374.

Slameto. (2010). Belajar dan Faktor-faktor yang Mempengaruhinya. Jakarta: Rineka Cipta.

Sugiyono, (2012). Metode penelitian kombinasi. Bandung: alfabeta, cv.

Sugiyono, (2014). Metode kuantitatif kualitatif dan R\&D. Bandung: Alfabeta

Susanto, E., \& Saylendra, N. P. (2018). Civic Education as Empowerment of Civic Activism. Annual Civic Education Conference.

Yamin, Matinis, (2007), Propesional Guru \& Implementasi KTSP. Jakarta: Gaung Persada Press

Zulfati Asmarina. (2015). Peran Pembelajaran Pendidikan Pancasila dan Kewarnrgaraan (PPKn) dalam menanamkan Nilai-nilai Pendidikan Anti Korupsi di SMKN 1 Kalibagor. Skripsi. Purwokerto: Program Studi Pendidikan Pancasila dan Kewarganegaraan Universitas Muhammadiyah Purwokerto. 